\title{
Effect of Ohmic Heating on Processing of Soymilk in Comparison to Conventional Process
}

\author{
Anupam Amitabh ${ }^{*}$, Vinita Kashyap², Manish Kumar ${ }^{3}$, \\ Anuradha Kumari ${ }^{3}$ and Vishal Kumar ${ }^{2}$ \\ ${ }^{1}$ ICAR-Central Institute of Agricultural Engineering, Bhopal, India \\ ${ }^{2}$ Department of Farm Machinery Power and Engineering, MPUAT, India \\ ${ }^{3}$ Department of Soil and Water Conservation Engineering, GBPUAT, India \\ ${ }^{4}$ Department of Processing and Food Engineering, Dr. RPCAU, Pusa, India \\ *Corresponding author
}

\begin{tabular}{|c|c|}
\hline & A B S T R A C T \\
\hline & \multirow{4}{*}{$\begin{array}{l}\text { The effect of ohmic heating on processing of soymilk in comparison to } \\
\text { conventional process was studied. For this an ohmic heating system was setup to } \\
\text { serve the heating process. The body of ohmic heating system was made up of food } \\
\text { grade Polycarbonate material of diameter of } 95 \mathrm{~mm} \text { and height of } 75 \mathrm{~mm} \text {. Soymilk } \\
\text { samples were prepared by conventional process and compared with ohmically } \\
\text { cooked soymilk. Time required in case of complete processing of soymilk by } \\
\text { ohmic heating was observed to be less as compared to conventional process. } \\
\text { Energy consumption in soymilk processing through ohmic heating was also found } \\
\text { to be much less as compared to conventional process. Thus, adoption of ohmic } \\
\text { heating for cooking soybean in soymilk preparation can reduce the energy } \\
\text { consumption and increase the capacity of the existing system. The cost of ohmic } \\
\text { heating system will be less than that of steam boiler. }\end{array}$} \\
\hline $\begin{array}{l}\text { Ohmic heating, } \\
\text { Soymilk, } \\
\text { Polycarbonate, } \\
\text { Soybean. }\end{array}$ & \\
\hline Article Info & \\
\hline $\begin{array}{l}\text { Accepted: } \\
\text { 21 October } 2017 \\
\text { Available Online: } \\
\text { 10 December } 2017\end{array}$ & \\
\hline
\end{tabular}

\section{Introduction}

Ohmic heating is an alternative and advanced thermal processing method in which heat is internally generated by the passage of alternating electrical current (AC) through the food system that serves as an electrical resistance. The success of ohmic heating depends on the rate of heat generation in the system, electrical field strength, the electrical conductivity of the food, residence time and the method by which the food flows through the system. $\mathrm{OH}$ seems to allow obtaining value added products of a superior quality without compromising food safety (Parrot 1992; Castro et al., 2003; Tucker 2004; Pereira et al., 2007). Because the energy is almost entirely dissipated within the heated material, there is no need to heat intervening heat exchange walls - thus the process has close to $100 \%$ energy transfer efficiency (Salengke, 2010). Novel thermal and non thermal processing technologies based on physical techniques for food preservation have the potential to address the demands of the consumer and deliver high quality 
processed foods with an extended shelf life that are additive free and have not been subjected to extensive heat treatment. In case of processing of soymilk, heating is required to inactivate the enzymes which inhibit the activity of trypsin. Soaked soybean is ground in the form of slurry and then boiled to around 15 minutes. Generally soymilk contains around $7-8 \%$ total solids in it. Besides being rich in protein, vitamins and minerals, soymilk is a very economical, lactose free, highly digestible and nutritious alternative of dairy and meat centred diet. Heat treatment by conventional method destroys pathogens and spoilage of microorganisms but causes nutrient loss and flavour deterioration the juices due to high temperature and long-time of processing.

\section{Materials and Methods}

\section{Materials and equipments required}

The various materials required for undergoing this experimental work were freshly soybean. The equipment used were ohmic heater, ammeter, voltmeter, thermometer, scale, electronic balance, tray Dryer, $\mathrm{pH}$ meter, refrigerated centrifuge, vacuum oven and weighing balance.

\section{Ohmic heating system for liquids}

In order to undergo the ohmic heating of liquids an ohmic heating system was setup to serve the purpose. The experimental device consisted of a power supply, voltmeter, ammeter and a temperature indicator. The body of ohmic heating system was made up of food grade Polycarbonate material of diameter of $95 \mathrm{~mm}$ and height of $75 \mathrm{~mm}$. The top and bottom electrodes for ohmic heating system were made of Stainless Steel. The thickness of stainless steel electrode was 5 $\mathrm{mm}$. A stand was specially designed and made up of a height of $600 \mathrm{~mm}$ with tilting mechanism for ease of operation. A temperature indicator was inserted into the geometric centre of the cell. The temperature at the centre of the sample was used as the representative value, and was assumed to be spatially uniform because of its small size. The sample was sandwiched between two electrodes in the test cell. End caps, fitted with high grade stainless steel electrodes were held in place using aspring-loaded system which also served to prevent leakages. Current and voltage applied were monitored with ammeter and voltmeter, respectively. Current and temperature readings were noted at every 10 second intervals. This allowed real-time calculation of the total power input to the sample at any given time (Kulshrestha and Sastry, 2006; Shirsat et al., 2004).

\section{Ohmic heating of soybean}

\section{Soymilk processing through conventional process}

The amount of raw soybean used for processing in the experiment was $2 \mathrm{~kg}$. The soybean were first soaked for 4 hours. The weight of the soaked soybean was then found out (Fig. 2).

The soaked soybean were then placed in grinder cooker with 12 litres of water. Cooking of soybean slurry was done by passing steam from the boiler which is attached to the grinder cooker. Grinding takes place in the grinder cooker. Once the grinding and cooking operation of the mixture is completed it is passed into the de-odorizer.

As the name itself suggests, the de-odourizer removes the unwanted odour from the mixture. Finally after de-odourisation the milk formed is filtered through filter press. The semi- solid residue remaining is known as okara. It can also be used for making many products such as badi, etc. Generally 14 litres of milk and $4 \mathrm{~kg}$ of okarais obtained from 2 $\mathrm{kg}$ raw soybean. 


\section{Soymilk processing through ohmic heating}

The amount of raw soybean used for processing in the experiment was same as that used in the conventional process that is $2 \mathrm{~kg}$. The soybean was first soaked for 4 hours. The weight of the soaked soybean was then found out. The soaked soybean along with 5 litres of water was ohmically heated in an ohmic heating set up used for liquids. The ohmic heating set up used for heating soybean slurry was made up of food grade Polycarbonate material of a diameter of $270 \mathrm{~mm}$ and a height of $350 \mathrm{~mm}$ (Fig. 1 and 3).

The top and bottom electrodes for ohmic heating system were made of Stainless Steel. A temperature indicator was inserted into the geometric centre of the cell. The temperature at the centre of the sample was used as the representative value.

End caps, fitted with high grade stainless steel electrodes were held in place using aspringloaded system which also served to prevent leakages. Current and voltage applied were monitored with ammeter and voltmeter, respectively. The electric field strength used was $7.33 \mathrm{~V} / \mathrm{cm}$.

The completion of ohmic heating was tested by taking a small amount of sample for enzyme deactivation. A drop of urea on the small amount of sample indicates enzyme deactivation. If the indicator decolourised it indicated enzyme deactivation and hence completion of ohmic heating. The ohmically heated and cooked soybean slurry was then passed through cooking grinder for undergoing grinding operation. The ground sample was then passed through the deodourizer for removing the unwanted smell. Finally soymilk was obtained by passing it through filter press. The residue obtained is known as okara. In this process also generally 14 litres of milk and $4 \mathrm{~kg}$ of okara is obtained.

\section{Results and Discussion}

\section{Processing soymilk by ohmic heating}

In conventional method, soaked soybean is ground in required water and the slurry is heated by injecting steam from a boiler. Soymilk samples were prepared by conventional process and compared with ohmically cooked soymilk.

In the new process, soaked soybean was cooked in ohmic heating system. The soaked soybean was dipped in 5 litres of water and electric current of $3 \mathrm{~A}$ to $17 \mathrm{~A}$ was passed. Electric field strength of $7.33 \mathrm{~V} / \mathrm{cm}$ was used. The temperature of the water and soybean was $25^{\circ} \mathrm{C}$ and this was heated to around $98^{\circ} \mathrm{C}$. The temperature was maintained for 15 minutes (Fig. 4).

After this the grains along with water were shifted to grinder. Remaining water (8 litres) was added and grinding was performed. After this de-odourisation and filtration were carried out in the same fashion as was done for conventional method. Soymilk samples were obtained.

No appreciable difference in the quality of soymilk was observed due to ohmic heating. The samples prepared by conventional method and new method were at par with respect to proximate composition. Even the colour and $\mathrm{pH}$ were found to be more or less similar.

Table 1 shows the various parameters tested by using Lacto scan Milk analyser. The table clearly indicates that soymilk prepared by conventional method and new method was at par with respect to proximate composition.

Time required in case of complete processing of soymilk by ohmic heating was observed to be less as compared to conventional process (Table 2). 
Fig.1 Schematic diagram of the ohmic heating system

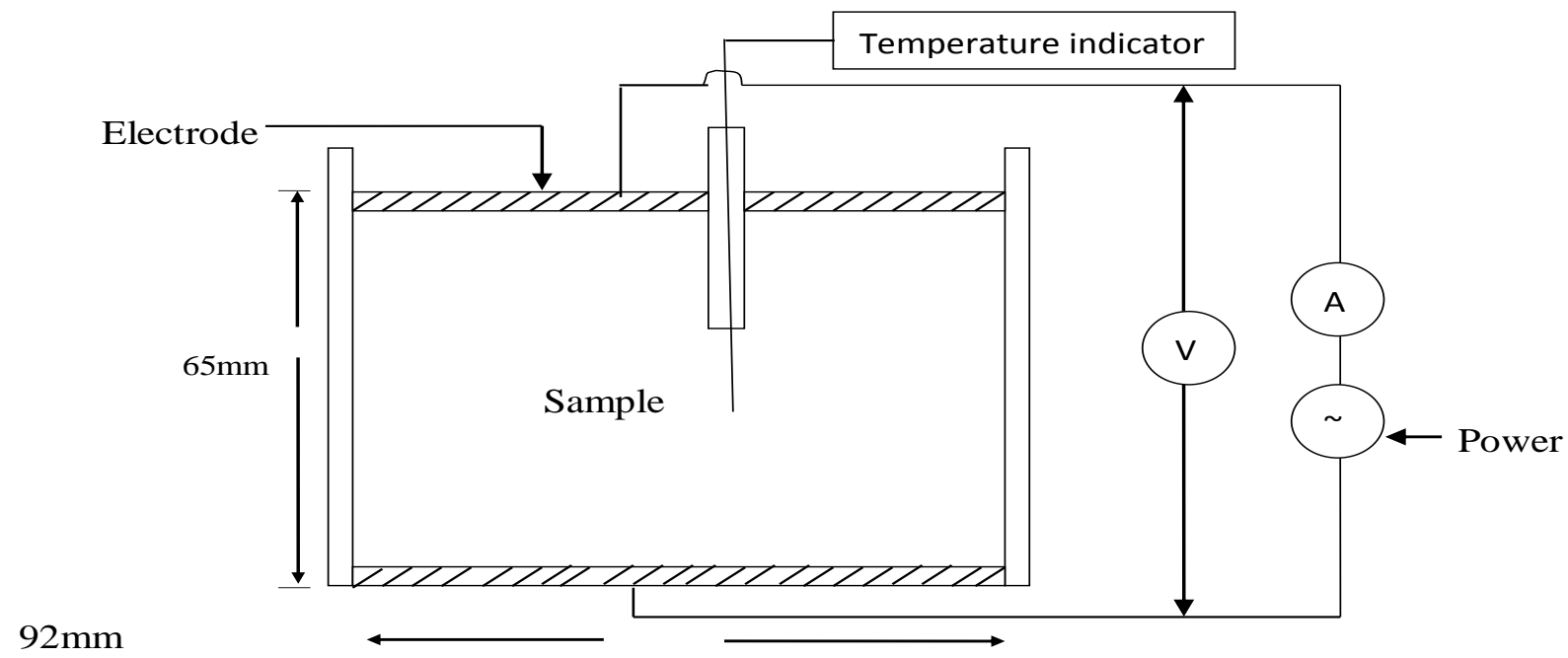

Fig.2 Flow chart showing the experimental procedure carried out during the conventional process of soymilk processing

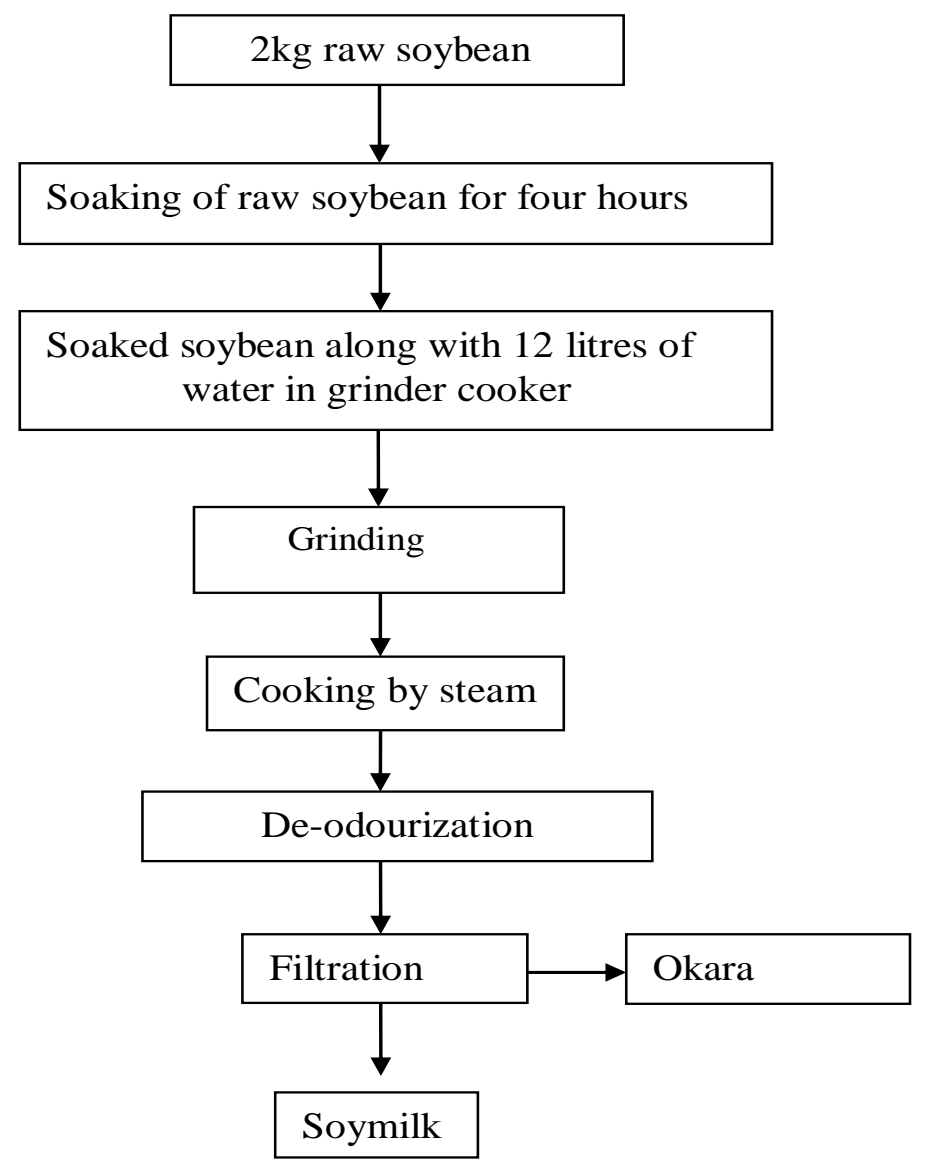


Fig.3 Ohmic heating system used for soybean

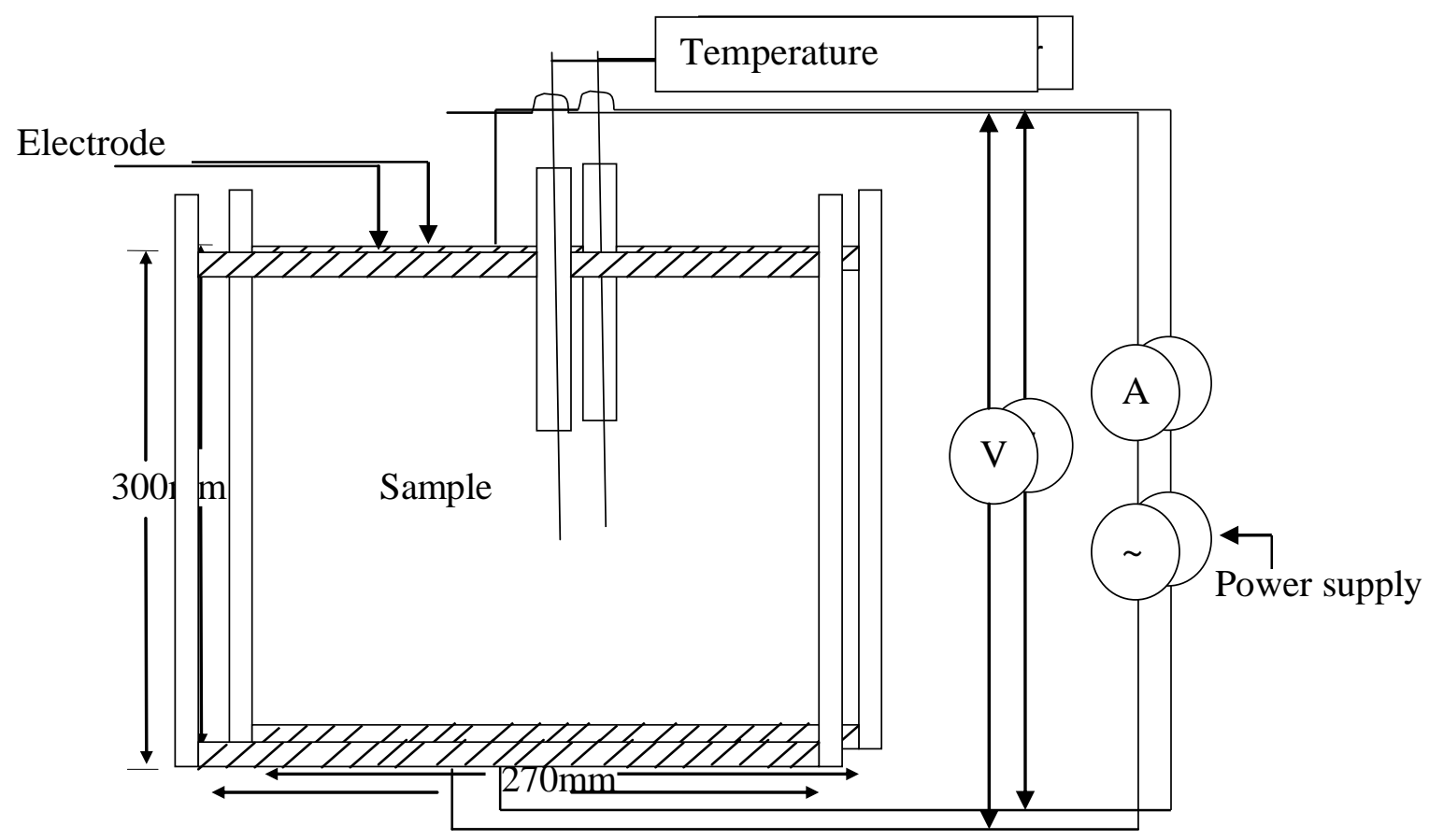

Fig.4 Flow chart showing the experimental procedure carried out during the ohmic heating process of soymilk processing

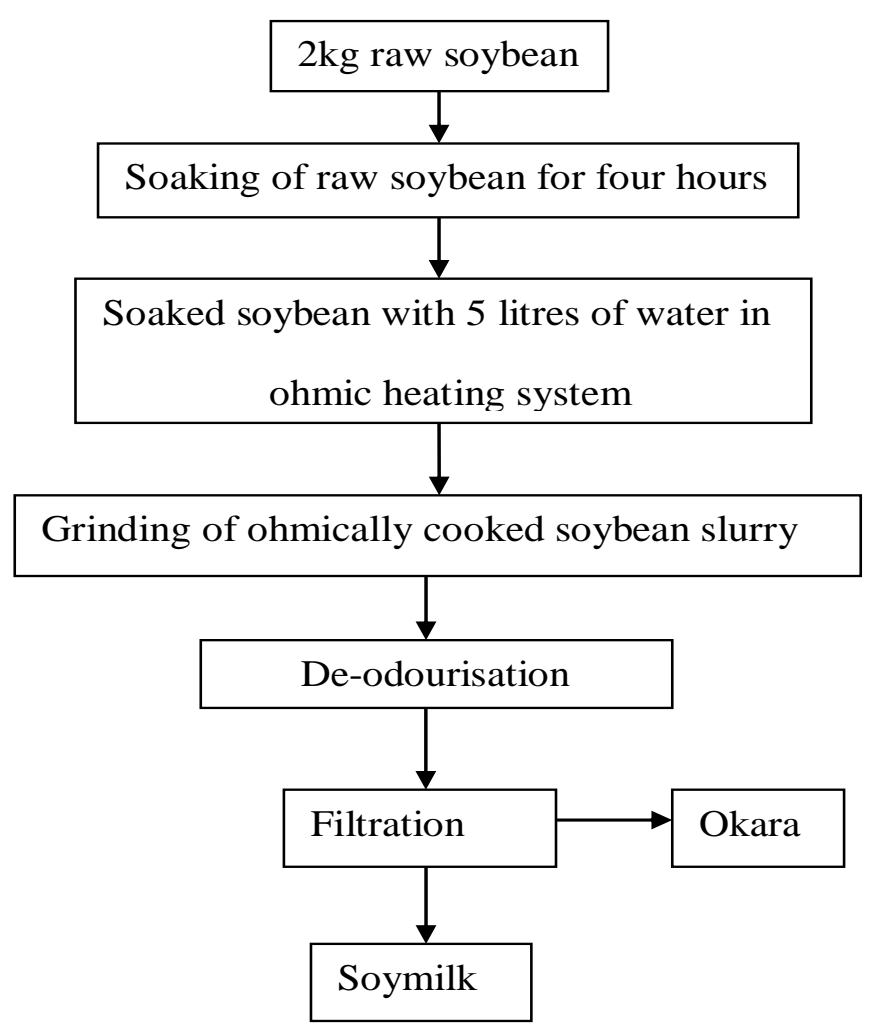


Table.1 Proximate composition of Soymilk prepared by ohmic heating and conventional Process

\begin{tabular}{|c|c|c|}
\hline \multirow[t]{2}{*}{ Parameters } & \multicolumn{2}{|c|}{ Contents (\%) } \\
\hline & $\begin{array}{l}\text { Soymilk processed by } \\
\text { Conventional process }\end{array}$ & $\begin{array}{l}\text { Soymilk processed by } \mathrm{Ohmic} \\
\text { heating }\end{array}$ \\
\hline Fat & 1.29 & 1.31 \\
\hline SNF & 4.39 & 4.75 \\
\hline Density & 15.49 & 17.10 \\
\hline Protein & 1.68 & 1.85 \\
\hline
\end{tabular}

Table.2 Time and energy consumption for soymilk processing

\begin{tabular}{|l|l|l|}
\hline & $\begin{array}{l}\text { Conventional process of } \\
\text { making soymilk (using } \\
\text { LPG fired boiler }\end{array}$ & $\begin{array}{l}\text { Ohmic heating of soybean } \\
\text { soaked in water }\end{array}$ \\
\hline Process time for one batch & 45 minutes & 30 minutes \\
\hline Energy used in one batch & $\begin{array}{l}500 \mathrm{~g} \text { LPG } \\
\text { (Rs. 40/- for commercial } \\
\text { LPG supply) }\end{array}$ & $\begin{array}{l}1.5 \mathrm{kWh}(\text { Rs. 6/kWh) } \\
\text { (Rs. 9 for electricity) }\end{array}$ \\
\hline Batch: 14 liters of milk from 2 kg soybean \\
\hline
\end{tabular}

The electrical conductivity increased linearly with increasing temperature.

Electrical conductivity was also dependent on electric field strength but comparatively lesser than temperature.

Ohmic heating rate was dependent on the electric field strengths used. Ohmic heating rate decreased with increase in electric field strength.

In conventional heating of particulate foods significant quality damage may occur due to slow conduction and convection heat transfer while ohmic heating volumetrically heats the entire mass of the food material, thus the resulting product is of far greater quality.

Over cooking of foods occur at the outside of the particles in case of conventional heating whereas ohmic heating causes no such damage to the food product. In conventional process integrity of particles is not maintained while lack of agitation in the ohmic heater maintains the integrity of particles and it is possible to process large particles (up to 2.5 $\mathrm{cm}$ ) that would be damaged in conventional equipment.

We can see from our present study that conventional process takes comparatively longer time for heating of foods.

The results indicated good potential of the ohmic heating system for thermal processing of soymilk.

Thus, finally it can be concluded that ohmic heating can be used as an alternative for processing of liquid and particulate foods.

\section{References}

Assiry, A M., Sastry, S K., Samaranayake, C P (2006). Influence of temperature, electrical conductivity, power and $\mathrm{pH}$ on ascorbic acid degradation kinetics during ohmic heating using stainless steel electrodes. Bioelectrochemistry. 68: 7-13. 
Ayadi, M A., Benezech, T., Chopard, F., Berthou, M (2008). Thermal performance of a flat ohmic cell under non fouling and whey protein fouling conditions. LWT. 41: 1073-1081.

Ayadi, M A., Leuliet, J C., Chopard, F., Berthou, M., Lebouché, M (2004). Electrical Conductivity of Whey Protein Deposit: Xanthan Gum Effect on Temperature Dependency. Food and Bioproducts Processing. 82(C4): 320-325

Benabderrahmane, Y., Pain, J.P. (2000). Thermal behaviour of a solid/liquid mixture in an ohmic heating sterilizer slip phase model. Chemical Engineering Science, 55: 1371-1384.

Bozkurt, H and Icier, F (2009). Rheological Characteristics of Quince Nectar During Ohmic Heating. International Journal of Food Properties. 12(4): 844-859.

Bozkurt, H and Icier, F (2010). Ohmic cooking of ground beef: Effects on quality. Journal of Food Engineering. 99: 481490.

Castro I., Macedo B., Teixeira JA., Vicente AA (2004). The Effect of Electric Field on Important Food processing Enzymes: Comparison of Inactivation Kinetics under Conventional and Ohmic Heating. Journal of Food Science. 69(9): 696-701.

Darvishi, H., Hosainpour, A., Nargesi, F., Khoshtaghaza, M H., Torang, H (2011). Ohmic Processing: Temperature Dependent Electrical Conductivities of Lemon Juice. Modern Applied Science. $5(1)$.

Halden, K., De Alwis, A A P., Fryer, P J (1990). Changes in the Electrical Conductivity of Foods during Ohmic Heating. International Journal of Food Science \& Technology. 25(1): 9-25

Icier, F and Ilicali, C (2005). Temperature dependent electrical conductivities of fruit purees during ohmic heating. Food Research International. 38: 1135-1142.

Icier, F and Ilicali, C (2004). The use of tylose as a food analog in ohmic heating studies. Journal of Food Engineering. 69: 67-77

Icier, F., Ilicali, C (2004). Electrical
Conductivity of Apple and Sourcherry Juice Concentrates During Ohmic Heating. Journal of Food Process Engineering. 27(3): 159-180.

Icier, F., Yildiz, H., Baysal, T(2006). Peroxidase inactivation and colour changes during ohmic blanching of pea puree. Journal of Food Engineering. 74: 424-429.

Jakób, C., Bryjak, J., Wójtowicz, H., Illeová, V., Annus, J., Polakovič, M (2010). Inactivation kinetics of food enzymes during ohmic heating. Journal of Food Chemistry. 123: 369-376.

Jun, S and Sastry, S (2005). Modeling and Optimization of Ohmic Heating of Foods inside a Flexible Package. Journal of Food Process Engineering. 28(4): 417436.

Knirsch, M C., Santosa, C A., Vicenteb, A M ., Penna, T C V (2010).Ohmic heating a review. Trends in Food Science \& Technology. 21: 436-441.

Kulshrestha, S A and Sastry, S K (2006). Low frequency dielectric changes in cellular food material from ohmic heating: Effect of end point temperature. Innovative Food Science and Emerging Technologies. 7: 257-262.

Lakkakula, N R., Lima, M., Walker, T (2004). Rice bran stabilization and rice bran oil extraction using ohmic heating. Bioresource Technology. 92: 157-161.

Legrand, A., Leuliet, J C., Duquesne, S., Kesteloot, R., Winterton, P., Fillaudeau, L (2007). Physical, Mechanical, Thermal and Electrical Properties of Cooked Red Bean (Phaseolus vulgaris L.) For Continuous Ohmic Heating Process. Journal of Food Engineering. 81(2): 447458.

Leizerson, S., Shimoni, E (2005). Stability and Sensory Shelf Life of Orange Juice Pasteurized by Continuous Ohmic Heating. Journal of Agricultural and Food Chemistry. 53(10): 4012-4018.

Lemmens, L., Tibäck, E., Svelander, C., Smout, C., Ahrné, L (2009). Thermal pretreatments of carrot pieces using 
different heating techniques: Effect on quality related aspects. Innovative Food Science and Emerging Technologies. 10: 522-529.

Marra, F., Zell, F., Lyng, J G., Morgan, D J., Cronin, D A (2009). Analysis of heat transfer during ohmic processing of a solid food. Journal of Food Engineering. 91: 56-63

McKenna, B M., Lyng, J., Brunton, N., Shirsat, N (2006). Advances in radio frequency and ohmic heating of meats. Journal of Food Engineering. 77: 215-229

Pereira, R N., Teixeira, J A,Vicente, A A(2010). Denaturation of whey proteins of milk during ohmic heating. Semana de Engenharia.

Ranmode, S., Kulshreshtha, M (2011). Enhancement of juice recovery from carrot using 2 stage processing with ohmic heating. Journal of Engineering Science and Technology. 6(2): 228-239.

Ruan, R., Chen, P., Chan, K., Kim, H J., Taub, I A (1999). Rapid Food Particle Temperature Mapping During Ohmic Heating Using FLASH MRI. Journal of Food Science. 64(6): 1024.

Salengke, S and Sastry, S K (2007). Models for ohmic heating of solid-liquid mixtures under worst case heating scenarios. Journal of Food Engineering. 83: 337355.

Sarang, S., Sastry, S K., Gaines, J., Yang, T C S., Dunne, P (2007). Product Formulation for Ohmic Heating: Blanching as a Pretreatment Method to Improve Uniformity in Heating of Solid-Liquid Food Mixtures. Journal of Food Science. 72(5): 227-234A.

Shim, J Y., Lee, S H., Jun, S (2010). Modeling of ohmic heating patterns of multiphase food products using computational fluid dynamics codes. Journal of Food Engineering. 99:136-141.

Shirsat, N., Lyng, J G., Brunton, N P., McKenna, B (2003). Ohmic processing: Electrical conductivities of pork cuts. Meat Science, 67: 507-514.

Singh, H., Singh, S P., Tarsikka, P S (2008).
Study on Viscosity and Electrical Conductivity of Fruit Juices. Journal of Food Science and Technology. 45(4): 371-372.

Soojin Jun, S., Sastry, S., Samaranayake, C (2007). Migration of electrode components during ohmic heating of foods in retort pouches. Innovative Food Science and Emerging Technologies. 8: 237-243.

Souza, B D S., Cerqueira, M A., Casariego, A., Lima, A M P., Teixeira, J A., Vicente, A A (2009). Effect of moderate electric fields in the permeation properties of chitosan coatings. Food Hydrocolloids. 23: 2110-2115.

Srikalong, P., Makrudin, T., Sampavamontri, P., Kovitthaya, E (2011). Effect of Ohmic Heating on Increasing Guava Juice Yield. International Conference on Biotechnology and Food Science IPCBEE. 7.

Stancl, J and Zitny, R (2010). Milk Fouling at Direct Ohmic Heating. Journal of Food Engineering. 99(4): 437-444.

Tham, H J., Chen, X D., Brent, R., Duffy, G (2009). Ohmic heating of dairy fluids effects of local electric field on temperature distribution. Asia Pac. J. Chem. Eng. 4: 751-758.

Tulsiyan, P., Sarang, S., Sastry, S K (2008). Electrical Conductivity of Multicomponent Systems During Ohmic Heating. International Journal of Food Properties. 11(1): 233-241.

Vikram, V B., Ramesh, M N., Prapulla, S G (2005). Thermal degradation kinetics of nutrients in orange juice heated by electromagnetic and conventional methods. Journal of Food Engineering, 69: 31-40.

Wu, H., Kolbe, E., Flugstad, B., Park, J W., Yongsawatdigul, J (1998). Electrical Properties of Fish Mince during Multi frequency Ohmic Heating. Journal of Food Science. 63(6): 1028-1032.

Zell, M., Lyng, J G., Cronin, D A., Morgan, D J (2009). Ohmic heating of meats: Electrical conductivities of whole meats 
and processed meat ingredients. Meat Science. 83: 563-570.

Zell, M., Lyng, J G., Morgan, D J., Cronin, D A (2009). Development of rapid response thermocouple probes for use in a batch ohmic heating system. Journal of Food Engineering. 93: 344-347.

Zhao, Y., Kolbe, E., Flugstad, B (1999). A method to characterise electrode corrosion during ohmic heating. J Food Process Eng. 22: 81-89.

Zhu, S M., Zareifard, M R., Chen, C R., Marcotte, M., Grabowski S (2010). Electrical conductivity of particle-fluid mixtures in ohmic heating: Measurement and simulation. Food Research International. 43: 1666-1672.

\section{How to cite this article:}

Anupam Amitabh, Vinita Kashyap, Manish Kumar, Anuradha Kumari and Vishal Kumar. 2017. Effect of Ohmic Heating on Processing of Soymilk in Comparison to Conventional Process. Int.J.Curr.Microbiol.App.Sci. 6(12): 2918 2926. doi: https://doi.org/10.20546/ijcmas.2017.612.339 